\title{
INFECTIOUS EXACERBATION OF BRONCHIECTASIS SUCCESSFULLY TREATED WITH CEFTRIAXONE/SULBACTAM/DISODIUM EDETATE-1034 (ELORES $\left.{ }^{\mathrm{TM}}\right)$
}

\author{
PARAG SHARMA* \\ Department of , Chirayu Medical College and Hospital, Bhopal, Madhya Pradesh, India. Email: docparagsharma@gmail.com
}

Received: 12 October 2016, Revised and Accepted: 22 December 2016

\section{ABSTRACT}

Bronchiectasis is a type of chronic obstructive pulmonary disease, defined as permanent abnormal dilation of bronchi due to vicious cycle of transmural infection and inflammation. Bronchiectasis is generally characterized by cough, wheeze, and dyspnea. Pathogens responsible for bronchiectasis include pathogens Haemophilus influenzae, Pseudomonas aeruginosa, Streptococcus pneumoniae, Staphylococcus aureus, and nontuberculous mycobacteria. Empirical antibiotic therapy and other drugs are used empirically in the management of bronchiectasis.Here, we discuss a case of infectious exacerbation of bronchiectasis successfully treated with an empirical use of ceftriaxone/sulbactam/disodium edetate-1034.

Keywords: Bronchiectasis, Elores ${ }^{\mathrm{TM}}$, Ceftriaxone/sulbactam/disodium edetate-1034, Disodium edetate, Antibiotic resistance.

(C) 2017 The Authors. Published by Innovare Academic Sciences Pvt Ltd. This is an open access article under the CC BY license (http://creativecommons. org/licenses/by/4. 0/) DOI: http://dx.doi.org/10.22159/ajpcr.2017.v10i3.15791

\section{INTRODUCTION}

Chronic obstructive pulmonary disease (COPD) is characterized by airflow limitation [1]. COPD is the fifth major cause of global mortality [1]. Bronchiectasis is a type of COPD, defined as permanent abnormal dilation of bronchi due to vicious cycle of transmural infection and inflammation [2]. Bronchiectasis is generally characterized by cough, wheeze, and dyspnea [3]. COPD and bronchiectasis are major cause of mortality and may be life threatening if not treated timely [2]. In bronchiectasis, internal bronchial diameter is more than adjacent pulmonary artery and thickening of the bronchial wall [3]. An American study reported 52 cases of bronchiectasis per 100,000 subjects [4]. In a German study, $40 \%$ of bronchiectasis-associated deaths occurred in hospital. This study reported an increase in hospitalization at rate of $2.9 \%$ per year [5]. In a British Thoracic Society, audit in 2011, annual exacerbation rate in bronchiectasis patients found to be $2.6 \%$ [6]. Bronchiectasis leads to prolonged hospitalization [3,6]. Identification of exacerbation is more complex in bronchiectasis. In a retrospective study on 100 bronchiectasis patients, Bopaka et al. in 2015, found $35 \%$ cases with microbial pathogens [7]. The reason for the lower prevalence of bacterial pathogens may be because sampling in $60 \%$ cases was done after initiation of antibiotic therapy [7].

Pathogens responsible for bronchiectasis include pathogens Haemophilus influenzae, Pseudomonas aeruginosa, Streptococcus pneumoniae, Staphylococcus aureus, and nontuberculous mycobacteria [7-9]. Empirical antibiotic therapy and other drugs are used empirically in the management of bronchiectasis [6]. Early initiation of antibiotics in acute exacerbation of bronchiectasis will be beneficial in the management of disease $[3,10]$.

Increased resistance of pathogens toward antibiotics leads to demand for newer antibiotics. Elores is a novel antibiotic adjuvant entity consisting of ceftriaxone, sulbactam and disodium edetate (EDTA) which has shown broad-spectrum activity in lower respiratory tract infections [11].

We present a case of infectious exacerbation of bronchiectasis successfully treated with ceftriaxone/sulbactam/disodium edetate (CSE-1034), an antibiotic adjuvant entity.

\section{CASE REPORT}

A 70-year-old male patient was admitted to hospital in ICU with complaints of dyspnea, cough with expectoration and fever. The patient had history of pulmonary tuberculosis and was on anti-tubercular treatment. On examination, patient's vitals were blood pressure of $140 / 90 \mathrm{mmHg}$, pulse rate: $120 /$ minute, $\mathrm{SPO}_{2} 80 \%$.

Systemic examination revealed cardiovascular system: Normal S1 S2, per abdomen soft and nontender, central nervous system: Conscious and oriented. Chest examination showed decreased air entry on right side. Jugularvein pressure was increased. Physical examination revealed pedal edema. Biochemical parameters were total bilirubin $17 \mathrm{mg} / \mathrm{dl}$, direct bilirubin $0.12 \mathrm{mg} / \mathrm{dl}$, indirect bilirubin $16.88 \mathrm{mg} / \mathrm{dl}$, SGOT $24.87 \mathrm{U} / \mathrm{l}$, SGPT $14.48 \mathrm{U} / \mathrm{l}$, Alkaline phosphatase $44.59 \mathrm{U} / \mathrm{l}$, Total serum proteins $4.89 \mathrm{~g} / \mathrm{dl}$, serum albumin $2.71 \mathrm{~g} / \mathrm{dl}$, serum globulin $2.18 \mathrm{~g} / \mathrm{dl}$, Urea $15.46 \mathrm{mg} / \mathrm{dl}$, serum creatinine $0.94 \mathrm{mg} / \mathrm{dl}$. X-ray examination showed right-sided pleural effusion with bilateral pneumonia. The patient had received levofloxacin and piperacillin+tazobactam at private hospital for a duration of 5 days. Thus based on clinical, hematological, biochemical, and radiological examination patient was diagnosed of infectious exacerbation of bronchiectasis.

Patient was empirically given CSE-1034 (Elores ${ }^{\mathrm{TM}}$ ) $1.5 \mathrm{~g}$ iv twice a day via iv infusion for 90 minutes. Patient was conservatively managed and supportive treatment (nebulization with formamide, prednisone $10 \mathrm{mg} \mathrm{q}$ 24 hrs orally, esomeprazole $400 \mathrm{mg}+$ domeperidone $30 \mathrm{mg} \mathrm{q} 12 \mathrm{hrs}$ orally, tamsulosin $0.2 \mathrm{mg} \mathrm{q} 24$ hrs orally, aspirin $75 \mathrm{mg}+$ rosuvastatin $75 \mathrm{mg}+$ clopidogrel 75 mg q 24 hourly, etizolam 0.5 mg + escitalopram 10 mg q 24 hrs at bed time) was given. Biochemical parameters on fourth day were total bilirubin: $0.16 \mathrm{mg} / \mathrm{dl}$, direct bilirubin: $0.07 \mathrm{mg} / \mathrm{dl}$, indirect bilirubin: $0.09 \mathrm{mg} / \mathrm{dl}$, SGOT: $18.28 \mathrm{U} / \mathrm{l}, \mathrm{SGPT}$ : $16.04 \mathrm{U} / \mathrm{l}$, alkaline phosphatase: $49.28 \mathrm{U} / \mathrm{l}$, total serum proteins: $5.59 \mathrm{~g} / \mathrm{dl}$, serum albumin: $3.22 \mathrm{~g} / \mathrm{dl}$, serum globulin: $2.37 \mathrm{~g} / \mathrm{dl}$, urea: $18.96 \mathrm{mg} / \mathrm{dl}$, serum creatinine: $0.87 \mathrm{mg} / \mathrm{dl}$.

On fifth day, patient had symptomatic relief except dyspnea and had no fever, no chest pain, and no cough. Patient continued on same medications.

On ninth day, patient complained of fever, dyspnea, and cough. Patient was started with Injection dexamethasone $8 \mathrm{mg} \mathrm{q} 12 \mathrm{hrs}$, azithromycin 
$500 \mathrm{mg}$ od orally, paracetamol $500 \mathrm{mg} \mathrm{q} 12 \mathrm{hrs}$ orally, esomeprazole $400 \mathrm{mg}+$ domperidone $30 \mathrm{mg} \mathrm{q} 12 \mathrm{hrs}$ orally, acebrophylline $100 \mathrm{mg} \mathrm{q}$ $12 \mathrm{hrs}$ orally and nebulization with formemide, Elores ${ }^{\mathrm{TM}} 1.5 \mathrm{~g}$ q $12 \mathrm{hrs}$ via iv infusion for 90 minutes was continued.

On $13^{\text {th }}$ day, dyspnea improved and patient continued to show improvement in symptoms and general health. The patient was shifted from ICU to ward on the $13^{\text {th }}$ day of admission.

On $15^{\text {th }}$ day his blood pressure was $130 / 80 \mathrm{mmHg}$, pulse $90 /$ minute and $\mathrm{SPO}_{2} 94 \%$. Patient was afebrile. Cardiovascular examination revealed S1 S2 normal. Hematological parameters were hemoglobin: $12.5 \mathrm{~g} / \mathrm{dl}$, total leukocyte count: $7200 /$ cumm, red blood cells count: 4.3 million/cumm, platelets: $347000 /$ cumm. He had normal renal function test, urea: $18.96 \mathrm{mg} / \mathrm{dl}$, serum creatinine: $0.87 \mathrm{mg} / \mathrm{dl}$. Patient was clinically cured and discharged on $15^{\text {th }}$ day of admission. Fig. 1 showed schematic representation of clinical picture of patient.

\section{DISCUSSION}

Bronchiectasis may require extensive medical care and hospitalization [12]. The aim of treatment for bronchiectasis is to improve the quality of life, eradicate the bacterial pathogen, and symptomatic relief.

The current report presents a case of 70 -year-old male patient suffering from acute infectious exacerbation of bronchiectasis.

Patient empirically started, with CSE-1034 (Elores ${ }^{\mathrm{TM}}$ ) $1.5 \mathrm{~g} \mathrm{q} 12 \mathrm{hrs}$ via IV infusion for $12 \mathrm{hrs}$. Guidelines and literature recommended early use of empirical antibiotic therapy for management of exacerbation of bronchiectasis [3]. CSE-1034 was selected as empirical therapy in this case. In a large number of cases of LRTI, no pathogen was found because of inappropriate techniques or the pathogen was missed [13]. Elore $\mathrm{S}^{\mathrm{TM}}$ is antibiotic adjuvant entity very effective in MDR, extended-spectrum-beta-lactamases (ESBL) and metallo beta-lactamase (MBL) pathogens [11]. CSE-1034 (ceftriaxone/sulbactam/disodium edetate) was empirically selected for treatment of bronchiectasis because of its established safety, efficacy and broad spectrum activity against ESBL/MBL producing pathogens in LRTI [11].

Antibiotic resistance is one of the major reasons for failure of antibiotic therapy. Antibiotic resistance is increasing in pathogens like Acinetobacter baumannii, H. influenza P. aeruginosa, Klebsiella pneumoniae, Klebsiella oxytoca, S. aureus [11]. These pathogens develop resistance to antibiotic mainly by overexpression of efflux pump, biofilm formation, production of ESBLs and MBLs and change in membrane permeability [11,14-16]. Use of disodium edetate along with ceftriaxone and sulbactam i.e., CSE-1034, drastically reduces antibiotic resistance by acting on different antibiotic resistance mechanisms, i.e., by downregulating the efflux pump, destruction of biofilms by increasing porosity, inhibiting MBL activity by chelation of zinc ions, enhancing penetration of ceftriaxone sulbactam through bacterial cell [15-19].

A randomized, multi-centered phase 3 study on 93 subjects with LRTI, Elores showed significantly better clinical cure rates as compared to ceftriaxone [11].

A study conducted on 663 clinical isolates (from sputum, blood, urine, and pus), showed overall prevalence of ESBL $82.5 \%$. The clinical isolated detected were P. aeruginosa (89 \%) Escherichia coli (85.3\%), K. pneumoniae $(76.6 \%)$, K. oxytoca $(73.0 \%)$, A. baumannii $(72.2 \%)$ and S. aureus (31.2\%). Susceptibility of CSE-1034 against these ESBL producing isolates was $95.7 \%$ with minimum inhibitory concentration of $0.125-8 \mathrm{mcg} / \mathrm{ml}$. Whereas susceptibilities were $<45 \%$ against all isolates with piperacillin and tazobactam, amoxicillin and clavulanic acid, cefoperazone and sulbactam [20].

As the patient had previously received levofloxacin and piperacillin+tazobactam, and patient did not respond to given antibiotics so these antibiotic were not continued as empirical therapy $[5,10]$. As use of intravenous antibiotics is recommended, initially so CSE-1034 was given via iv infusion [5].

\begin{tabular}{|c|c|}
\hline Day1 & $\begin{array}{l}\text { - Complaints of dyspnea, cough with expectoration and fever } \\
\text { - X ray showed right sided pleural effusion with bilateral pneumonia } \\
\text { - Diagnosed with infectious exacerbation of Bronchiectasis }\end{array}$ \\
\hline & $\begin{array}{l}\text { - CSE- } 10341.5 \mathrm{~g} \text { q12h via iv infusion } \\
\text { - Patient was given other supportive medicine }\end{array}$ \\
\hline & $\begin{array}{l}\text { - Symptomatic relief (no fever and no cough) } \\
\text { - Dyspnea } \\
\text {-Patient continued on same medications. }\end{array}$ \\
\hline & $\begin{array}{l}\text {-Fever, dyspnea and cough } \\
\text { - CSE-1034 } 1.5 \mathrm{~g} \text { q12h via iv infusion for } 90 \text { minutes continued. }\end{array}$ \\
\hline & $\begin{array}{l}-\mathrm{SPO}_{2} 98 \% \\
\text { - Gradual improvement was observed }\end{array}$ \\
\hline & -Patient was clinically stable \& was transferred to ward \\
\hline & $\begin{array}{l}\text {-Afebrile and TLC: } 7200 / \text { cumm } \\
\text { - Clinically cured and discharged }\end{array}$ \\
\hline
\end{tabular}

Fig. 1: Schematic representation of clinical course for management of hospital acquired pneumonia in a 70-year-old patient 
Prednisolone $10 \mathrm{mg} \mathrm{q} 24$ hrs orally helps in the management of COPD. Moreover, studies reported reduced duration of hospitalization in COPD by using low dose of oral corticosteroids [21].

Patient was provided with other supportive medicines (esomeprazole $400 \mathrm{mg}+$ domeperidone $30 \mathrm{mg} \mathrm{q} 12$ hrs orally, tamsulosin $0.2 \mathrm{mg} \mathrm{q}$ 24 hrs orally, aspirin $75 \mathrm{mg}$ + rosuvastatin $75 \mathrm{mg}$ + clopidogrel $75 \mathrm{mg} \mathrm{q}$ 24 hourly, etizolam $0.5 \mathrm{mg}+$ escitalopram $10 \mathrm{mg} \mathrm{q} 24 \mathrm{hrs}$ at bed time.] for effective management of disease.

Patient responded well to the empirical therapy of Elores. Patient was shifted from ICU toward in 13 days with clinical improvement and relief in symptoms of cough and dyspnea. The patient was discharged after clinical cure with the use of CSE-1034 on the $15^{\text {th }}$ day with normal TLC count, normal body temperature. This case suggests that CSE-1034 can be a valuable drug to treat infectious exacerbation of bronchiectasis.

\section{CONCLUSION}

New Antibiotic Adjuvant Entity, i.e., CSE-1034 may be a preferred choice as empirical therapy in acute infection of exacerbation in bronchiectasis which may be caused by ESBL producing Gram-negative pathogens, or MDR bugs. Along with aggressive supportive management treatment. Hence, Elores ${ }^{\mathrm{TM}}$ can be a safer alternative and may be used as initial broad spectrum antibiotic to cover probable MDR pathogens for the management of exacerbation in bronchiectasis.

\section{REFERENCES}

1. Rabe KF. Guidelines for chronic obstructive pulmonary disease treatment and issues of implementation. Proc Am Thorac Soc 2006;3(7):641-4.

2. Bilton D, Jones AL. Bronchiectasis: Epidemiology and causes. Eur Respir Monogr Eur Respir Mon 2011;52:1-10.

3. Pasteur MC, Bilton D, Hill AT. British thoracic society bronchiectasis non-CF guideline Group. British thoracic society guideline for non-CF bronchiectasis. Thorax 2010;65 Suppl 1:i1-58.

4. Weycker D, Edelsberg J, Oster G, Tino G. Prevalence and economic burden of bronchiectasis. Am J Respir Crit Care Med 2004;169:A330.

5. Ringshausen FC, de Roux A, Pletz MW, Hamalainen N, Welte T, Rademacher J. Bronchiectasis-associated hospitalizations in Germany, 2005-2011: A population-based study of disease burden and trends. PLoS One 2013;8(8):e71109.
6. HillAT, Welham S, Reid K, Bucknall CE. British thoracic society national bronchiectasis audit 2010 and 2011. Thorax 2012;67(10):928-30.

7. Bopaka RG, Khattabi WE, Janah H, Jabri H, Afif H. Bronchiectasis: A bacteriological profile. Pan Afr Med J 2015;22:378.

8. Barker AF. Bronchiectasis. N Engl J Med 2002;346:1383-93.

9. Shah PL, Mawdsley S, Nash K, Cullinan P, Cole PJ, Wilson R. Determinants of chronic infection with Staphylococcus aureus in patients with bronchiectasis. Eur Respir J 1999;14:1340-4.

10. Bronchiectasis. In: European Lung White Book. Available from: http:// www.erswhitebook.org/chapters/bronchiectasis/. [Last accessed on 2016 Sep 21].

11. Chaudhary M, Payasi A. A randomized, open-label, prospective, multicenter phase-III clinical trial of Elores in lower respiratory tract and urinary tract infections. J Pharm Res 2013;6:409-14.

12. Seitz AE, Olivier KN, Steiner CA, de Oca RM, Holland SM, Prevots DR. Trends and burden of bronchiectasis-associated Hospitalizations in the United States, 1993-2006. Chest 2010;138(4):944-9.

13. Woodhead M, Blasi F, Ewig S, Garau J, Huchon G, Ieven M, et al. Joint taskforce of the European respiratory society and European society for clinical microbiology and infectious diseases. Guidelines for the management of adult lower respiratory tract infections. Clin Microbiol Infect 2011;17(6):E1-59.

14. Byarugaba DK. Mechanisms of antimicrobial resistance. In: Sosa AJ, Byarugaba DK, Amabile C, editors. Antimicrobial Resistance in Developing Countries. Springer Science Business Media, LLC; 2009. DOI 10.1007/978-0-387-89370-9 2.

15. Chaudhary M, Kumar S, Payasi A. A novel approach to combat acquired multiple resistance in Escherichia coli by using EDTA as efflux pump inhibitor. J Microb Biochem Technol 2012;4:126-30.

16. Chaudhary M, Kumar S, Payasi A. Role of CSE1034 in Escherichia coli biofilm destruction. J Microb Biochem Technol 2013;5:54-8.

17. Chaudhary M, Sudaroli M, Kumar S, Krishnaraju V. Catering ESBL resistance challenge through strategic combination of ceftriaxone, sulbactam and ethylenediamine tetraacetic acid. Int J Drug Dev Res 2012;4(1):72-81.

18. Chaudhary M, Payasi A. Ethylenediamine tetraacetic acid: A non antibiotic adjuvant enhancing Pseudomonas aeruginosa susceptibility. Afr J Microbiol Res 2012;6:6799-804.

19. Monograph. Baddi, India: Venus Medicine Research Center

20. Chaudhary M, Payasi A. Molecular characterization and in vitsosceptibilities of $\beta$-lactamase producing Escherichia coli, Klebsiella species, Acinetobacter baumannii, Pseudomonas aeruginosa and Staphylococcus aureus to CSE1034 and other $\beta$-lactams. Asian Pac J Trop Med 2014;7:S217-23

21. Wedzicha JA. Oral corticosteroids for exacerbations of chronic obstructive pulmonary disease. Thorax 2000;55:S23-7. 